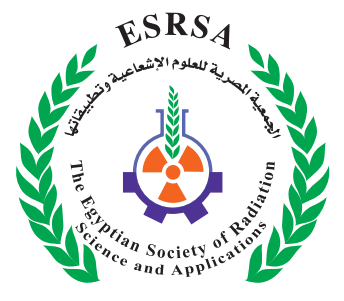

J. Nucl. Tech. Appl. Sci., Vol. 8, PP. 153 : 162 (2020)

\title{
Silica Nano Particles Bait Against the Black Cutworm, Agrotis Ipsilon (Hufn.)
}

Mesbah, H.A. ${ }^{1}$; Tayeb, E.H. ${ }^{1}$; Mourad, A.K. ${ }^{1}$; El-Shershaby, M. M.A. ${ }^{2}$; El-Wakil, N.H. ${ }^{2}$ and Kordy, A.M. ${ }^{1}$

Received: 06/08/2020

Accepted: 18/10/2020

DOI: $10.21608 /$ jntas.2020.38203.1026

E.mail:akkm05@gmail.com

\section{KEYWORDS}

Nanoparticles, Silica, Agrotis Ipsilon, Haemolymph.

\section{ABSTRACT}

The present study was conducted to determine the effect of baits containing nano particles of silica against the fourth instar larvae of Agrotis ipsilon (Hufn.) along sequential daily intervals post treatment under laboratory conditions. The determined percentages of larval mortality due to the admixed baits with SiNPs increased up to $100 \%$ after 15 days of application. The admixing of nanoparticles of silica in the bait during the sensitive period of larval development caused morphological abnormalities that are generally irreversible and often lead to death, beside certain biochemical changes of some inorganic elements in the haemolymph of the treated insects. It could be concluded that the tested nanoparticles of silica were most effective and indicated the highest concentration reductions of inorganic constituents in larval haemolymph, especially calcium, sodium and potassium.

Therefore, more attention must be directed towards the inorganic constituents in the larval haemolymph as biomarkers for SiNPs efficacy.

1. Plant Protection Dep., Faculty of Agriculture, Saba-Basha, Alexandria University, Egypt-

2. Plant Protection Research Institute, Agriculture Research Center, Giza, Egypt. 


\section{INTRODUCTION}

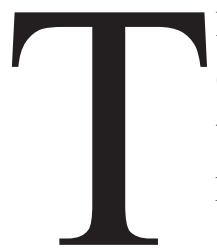

he black cutworm, Agrotis ipsilon (Hufn.) is considered to be one of the most notorious and destructive phytophagous insect pest in Egypt ; not only to cotton but also to many field crops and vegetables (Salama et al., 1970 and Kandil et al, 2003). Where the larvae on emergence feeds on the epidermis of the leaves. It attacks the young seedling of the plants at night. They feed on the plants by cutting their stem either below or just above the ground level (Shakur et al., 2007). Because of the severe damage caused by the attack of this pest, it was found necessary to replant many crop plantations in many years (Abdel Hadi, 1968 and Elkifl et al., 1972).

The black cutworm control is currently based on extensive use of insecticides, which affect the environment and/or pose a threat to public health via food residues, ground water or accidental exposure (Hazaa andAlam EL-Din, 2011). Nevertheless, due to resistance of insecticides and nocturnal feeding habits of the larvae, the black cutworm is considered to be very difficult to be controlled with insecticides (Han, 1986; Li et al., 2002 \& 2008). The excessive use of insecticides, particularly those with long residual effect, resulted in several harm to the natural balance between pests and their enemies by killing many non-target organisms, long storage and sometimes very slow degradation of the insecticides and in many cases high toxicity to mammals (Schmidt, 1986).

Reference to problems caused by insecticides and their residues; it is amplified the need for effective and biodegradable pesticides with greater selectivity. Therefore, there is a growing need for newer pesticides, which should fulfill the purpose of ensuring safety to end users and environment and prevent instant development of resistance in the target insects. There are scientific reports on the successful use of inert dust-based insecticides and their physi- cal mode of action behind their entomotoxic effect (Ebeling 1971; Golob 1997; Korunic 1998; Subramanyan et at. 2000). Commercial use of amorphous silica is approved by United States Department of Agriculture (USDA) (Slathers et al. 2004) and we hypothesized that silica nanoparticle (SNP) based insecticide is also physically active.

EPA has noted, "these novel products may allow for more effective targeting of pests, use of smaller quantities of a pesticide, and minimizing the frequency of spray-applied surface disinfection. These could contribute to improved human and environmental safety and could lower pest control costs" (Gopal et al., 2012). Nanomaterials (NMs) consist of one or more components present in various form that possess at least one-dimensional structure of diameters in the range of 1 to $100 \mathrm{~nm}$ (Warheit et al., 2008). Among NMs, the application of silica nanoparticles (SiNPs) can be easily integrated with other pest management practices. Concomitantly it affects biological parameters such as longevity and nymph production, thus reducing the reproductive potential of females and would therefore be a useful component of an integrated pest management strategy (El-bendary and El-Helaly, 2013).

The present research work was carried out to evaluate SiNPs as a new alternative insecticide on the black cutworm.

\section{MATERIALS AND METHODS}

\section{1-Experimental insects:}

\section{A. Source of the black cutworm, Agrotis ipsilon (Hufn.)}

The used larvae of $A$. ipsilon (Hufn.) in the present study were obtained as newly deposited eggs from the Department of Cutworm and Mole Crickets, Plant Protection Research Institute, Agriculture Research Center, Cairo, Egypt. The hatched larvae were subsequently reared on castor oil leaves (Ricinus communis L.) under the hygro-thermic con- 
ditions of $25 \pm 2^{\circ} \mathrm{C}$ and $65 \pm 5 \%$ R.H., for many generations to obtain the sufficient number of insects needed for the experiment.

\section{B. Rearing technique:}

According to the adopted rearing techniques by Beheedy (1990) and Abdel-Mageed (1997) the newly hatched larvae were kept in clean glass jar (1L.) and covered with muslin which was fixed tightly by a rubber band and provided daily with new fresh castor oil leaves until the third larval instar, then they were transferred to clean disinfected and larger glass jars (2L.) trays to limit or prevent cannibalism. The bottom of each jar was covered with a thick layer of fine saw dust and the usual rearing technique was performed along the developing stages of $4^{\text {th }}, 5^{\text {th }}$ and $6^{\text {th }}$ larval instars till pupation occurred. The developed pupae were kept in glass jars with paper towels on the bottoms and covered with gauze until adult emergence. The resulting adults (males and females in ratio 1:1) were transferred to a bigger jar which was supplied with hanged piece of cotton moistened with $20 \%$ sugar solution and covered with black muslin strips for egg deposition by the mated female moths. Swaps of cotton soaked in this solution were replaced every two days. Also, the muslin strips on which the eggs had been deposited were daily collected and transferred to new jars and left up to hatch. The neonates were fed on castor oil leaves and the colony of mass reared larvae was continued as above explained rearing technique. The needed $4^{\text {th }}$ instar larvae of the black cutworm for the initiated treatments were obtained from the colony.

\section{The used materials and techniques}

\section{A. Silica nanoparticles Product name: Silicon Dioxide Nanoparticles}

\section{Brand: NT-SiO2 NP}

One type of silica nanoparticles (SiNPs), namely hydrophilic nano-silica, $40 \mathrm{~nm}$ in diameters, was obtained from Nano Tech Egypt Co., Dreamland, Wahat Road, $6^{\text {th }}$ October, Egypt.

\section{B. The preparation of the evaluated silica nanoparticles (SiNPs)}

The included amounts in table, 1 elucidate the used components and rates of carrier material and stimulants in preparing the tested baits of the evaluated SiNPs during the study. Three different rates of SiNPS; 0.1, 0.25 and $0.5 \mathrm{gm}$, were used and added to the prepared bait. The exposure of the $4^{\text {th }}$ instar larvae to the SiNPs bait was performed in plastic pans $(10 \mathrm{~cm}$, in diameter), on which the bait was scattered in regular small amounts. Treatments were run in three replicates, each contained 10 larvae. The exposure of treated larvae on the bait extended along the lasted period from the beginning of the $4^{\text {th }}$ instar larvae till the end of the experiment. The percentages of larval mortality were recorded and $\mathrm{LC}_{50}$ values after 10 days were estimated. Mortality corrections were done and adjusted using Abbott's formula (Abbott, 1925). The data were analyzed using an adopted computer program based on a standard implementation of the probit analysis recommended by Finney (1971). The median lethal dose $\left(\mathrm{LC}_{50}\right)$ and its fiducial limits, the interception (a) and slope (b) parameters for the tested compounds were also calculated.

\section{Preparation of the cuticle}

The larvae were taken out of the deep freezer and allowed to come to room temperature before dissection, then they were placed in distilled water. The head of each larvae was cut off, the dorsal side of the body was longitudinally opened and the digestive system as well as the rest of the interval body contents were removed. Moreover, parietal fat bodies were accurately and completely removed because keeping the larvae in deep freezer facilitates their removal. Thereafter, the cuticle was rinsed twice in cold distilled water before drying.

Nextly, dry weight was determined by drying cuticles at $110^{\circ} \mathrm{C}$ up to a constant weight. Total chitin was determined by heating cuticles in sealed tubes with $2.5 \mathrm{~N}$ Sodium hydroxide $(\mathrm{NaOH})$ at $110^{\circ} \mathrm{C}$ for 
two hours. The residues were successively washed in distilled water, in hydrochloric acid, ethanol and diethyl ether according to the method of Hackman and Goldberg (1971).

The remaining insoluble material that assumed to be chitin was then dried to a constant weight. Total protein was determined by subtracting that weight from the cuticular dry weight.

\section{Inorganic elements (cations) concentrations}

The effect of the tested rates of SiNPs on the quantitative change of the inorganic elements in the haemolymph was investigated. The cations that have been detected in the haemolymph of treated larvae were potassium, sodium, calcium and phosphor using an atomic absorption instrument (Perkin Elmer2380). Haemolymph sample (1 ml.) was diluted to $20 \mathrm{ml}$ using distilled water.

Table (1): Amount of the used materials for preparing baits of the evaluated SiNPs in lab.

\begin{tabular}{|c|c|c|c|c|}
\hline \multirow{2}{*}{$\begin{array}{c}\text { Site of } \\
\text { application }\end{array}$} & \multicolumn{2}{|c|}{ Bait components } & \multicolumn{2}{c|}{ SiNPs } \\
\cline { 2 - 5 } & Carrier material of course corn flour & Water & Molasses & \\
\hline \multirow{2}{*}{ Lab } & $125 \mathrm{~g}$ & & & Tested progressive rates. \\
& & $100 \mathrm{ml}$ & $5 \mathrm{ml}$ & $\begin{array}{c}0.5,1,1.5,2,3 \mathrm{and} 4 \mathrm{~g} . \\
\text { Or } 0.1,0.25\end{array}$ \\
& & & and $0.5 \mathrm{~g}$. \\
\hline
\end{tabular}

\section{E. Statistical analysis:}

All data were Statistically analyzed using Analysis of Variances (ANOVA) which was run to compare the significance of differences between treatments. The least significant differences (L.S.D) were determined according to Duncan (1955).

\section{RESULTS AND DISCUSSIONS}

\section{The effect of prepared baits with tested additive rates of SiNPs against the black cutworm $\mathrm{A}$. ipsilon}

The efficiency of each of the tested rates of SiNPs in the prepared baits against the $4^{\text {th }}$ instar larvae of the black cutworm, A. ipsilon was carried out under the prevailing laboratory hygro-thermic conditions ( $25 \pm 2^{\circ} \mathrm{C}$ and $65 \pm 5 \%$ R.H. $)$.

The demonstrated results in Table (2) elucidate the detected influence of the evaluated rates of SiNPs on the recorded mortalities of the treated cutworm larvae during feeding on the prepared baits. The numbers and the percentages of the inspected dead larvae were calculated and recorded,
Data showed that the mortality percentages of the larvae were generally increased by rate increase. After four days, the lowest mortality percentage of $0.67 \%$ was recorded for the tested rate of $0.1 \mathrm{gm}$, versus the highest mortality percentage of $2.33 \%$ at the rate of $0.5 \mathrm{gm}$. At that higher rate of $0.5 \mathrm{gm}$, the mortality percentage of the dead larvae increased and reached $100 \%$ after 12 days from application. Meanwhile, after the same interval of 12 days the recorded percentages of larval mortality amounted to $63.33 \%$ at $0 . \operatorname{lgm}$ of SiNPs and $73.33 \%$ at the used rate of $0.25 \mathrm{gm}$ of SiNPs. Finally, all of the tested baits of admixed rates of SiNPs gave the highest percentage of larval mortality (100\%) after 15 days of application.

\section{Estimation of $L C$ values for the tested SiNPs} against the $4^{\text {th }}$ instar larvae of the black cutworm

\section{A. ipsilon}

The $\mathrm{LC}_{50}$ for SINPs was determined for the $4^{\text {th }}$ instar larvae of the black cutworm, A. ipsilon. The estimated values of the tested SiNPs against the larvae of $A$. ipsilon is shown in Table $3 \&$ fig 1 . Bioassay of SiNPs was evaluated after 10 days from appli- 
cation, where the $\mathrm{LC}_{50}$ value recorded $0.171 \mathrm{~g}$.

Therefore, SNP inducing dehydration was the main reason behind their nanocidal property. Due to their ultra-small size, SNPs got impregnated in in- sect cuticle and damaged the cuticular water barrier. This caused insects to lose water from their body and ultimately, they died because of desiccation (Golob 1997). As all three types of SNP formulations were

Table (2): Thee ffect of evaluated SiNPs baits on A. ipsilon larvae.

\begin{tabular}{|c|c|c|c|c|c|c|c|c|c|c|c|c|c|c|}
\hline \multirow{3}{*}{$\begin{array}{c}\text { SiNPs } \\
\text { rate (g) } \\
=w / w\end{array}$} & \multicolumn{14}{|c|}{ Interval of inspected dead larvae (days) } \\
\hline & \multicolumn{2}{|c|}{2} & \multicolumn{2}{|c|}{4} & \multicolumn{2}{|c|}{6} & \multicolumn{2}{|c|}{8} & \multicolumn{2}{|c|}{10} & \multicolumn{2}{|c|}{12} & \multicolumn{2}{|c|}{15} \\
\hline & $\mathbf{A}$ & B & $\mathbf{A}$ & B & $\mathbf{A}$ & B & $\mathbf{A}$ & B & $\mathbf{A}$ & B & $\mathbf{A}$ & B & $\mathbf{A}$ & B \\
\hline 0.1 & $\begin{array}{c}1.0 \\
(3.33) \\
\end{array}$ & $\begin{array}{l}0.33 \mathrm{a} \\
\pm 0.33 \\
\end{array}$ & $\begin{array}{c}2.0 \\
(6.67) \\
\end{array}$ & $\begin{array}{l}0.67 \mathrm{~b} \\
\pm 0.33 \\
\end{array}$ & $\begin{array}{c}5.0 \\
(16.67) \\
\end{array}$ & $\begin{array}{l}1.67 \mathrm{~b} \\
\pm 0.33 \\
\end{array}$ & $\begin{array}{c}10.0 \\
(33.33) \\
\end{array}$ & $\begin{array}{l}3.33 \mathrm{~b} \\
\pm 0.33\end{array}$ & $\begin{array}{c}12.0 \\
(40.0) \\
\end{array}$ & $\begin{array}{c}4.0 \mathrm{c} \\
\pm 0.58\end{array}$ & $\begin{array}{c}19.0 \\
(63.33) \\
\end{array}$ & $\begin{array}{l}6.33 \mathrm{c} \\
\pm 0.33 \\
\end{array}$ & $\begin{array}{c}30.0 \\
(100.0)\end{array}$ & $\begin{array}{c}10.0 \mathrm{a} \\
\pm 0.0 \\
\end{array}$ \\
\hline 0.25 & $\begin{array}{c}1.0 \\
(3.33) \\
\end{array}$ & $\begin{array}{r}0.33 \mathrm{a} \\
\pm 0.33 \\
\end{array}$ & $\begin{array}{c}3.0 \\
(10.0) \\
\end{array}$ & $\begin{array}{l}1.0 \mathrm{~b} \\
\pm 0.0 \\
\end{array}$ & $\begin{array}{c}5.0 \\
(16.67) \\
\end{array}$ & $\begin{array}{l}1.67 \mathrm{~b} \\
\pm 0.67 \\
\end{array}$ & $\begin{array}{c}13.0 \\
(43.33) \\
\end{array}$ & $\begin{array}{l}4.33 \mathrm{ab} \\
\pm 0.88 \\
\end{array}$ & $\begin{array}{c}18.0 \\
(60.0) \\
\end{array}$ & $\begin{array}{c}6.0 \mathrm{~b} \\
\pm 0.58 \\
\end{array}$ & $\begin{array}{c}22.0 \\
(73.33) \\
\end{array}$ & $\begin{array}{l}7.33 \mathrm{~b} \\
\pm 0.33 \\
\end{array}$ & $\begin{array}{c}30.0 \\
(100.0) \\
\end{array}$ & $\begin{array}{l}10.0 \mathrm{a} \\
\pm 0.0 \\
\end{array}$ \\
\hline 0.5 & $\begin{array}{c}3.0 \\
(10.0) \\
\end{array}$ & $\begin{array}{r}1.0 \mathrm{a} \\
\pm 0.58 \\
\end{array}$ & $\begin{array}{c}7.0 \\
(23.33) \\
\end{array}$ & $\begin{array}{r}2.33 \mathrm{a} \\
\pm 0.33 \\
\end{array}$ & $\begin{array}{c}13.0 \\
(43.33) \\
\end{array}$ & $\begin{array}{r}4.33 \mathrm{a} \\
\pm 0.33 \\
\end{array}$ & $\begin{array}{c}17.0 \\
(56.67) \\
\end{array}$ & $\begin{array}{l}5.67 \mathrm{a} \\
\pm 0.67 \\
\end{array}$ & $\begin{array}{c}25.0 \\
(83.33) \\
\end{array}$ & $\begin{array}{l}8.33 \mathrm{a} \\
\pm 0.33 \\
\end{array}$ & $\begin{array}{c}30.0 \\
(100.0) \\
\end{array}$ & $\begin{array}{l}10.0 \mathrm{a} \\
\pm 0.0 \\
\end{array}$ & $\begin{array}{c}30.0 \\
(100.0) \\
\end{array}$ & $\begin{array}{l}10.0 \mathrm{a} \\
\pm 0.0 \\
\end{array}$ \\
\hline $\begin{array}{c}\text { Check } \\
\text { untreated }\end{array}$ & $\begin{array}{c}0.0 \\
(0.0) \\
\end{array}$ & $\begin{array}{l}0.0 \mathrm{a} \\
\pm 0.0 \\
\end{array}$ & $\begin{array}{c}1.0 \\
(3.33) \\
\end{array}$ & $\begin{array}{l}0.33 \mathrm{~b} \\
\pm 0.33 \\
\end{array}$ & $\begin{array}{c}2.0 \\
(6.67) \\
\end{array}$ & $\begin{array}{l}0.67 \mathrm{~b} \\
\pm 0.33 \\
\end{array}$ & $\begin{array}{c}2.0 \\
(6.67) \\
\end{array}$ & $\begin{array}{c}0.67 \mathrm{c} \\
0.33 \\
\end{array}$ & $\begin{array}{c}2.0 \\
(6.67) \\
\end{array}$ & $\begin{array}{l}0.67 \mathrm{~d} \\
\pm 0.33 \\
\end{array}$ & $\begin{array}{c}2.0 \\
(6.67) \\
\end{array}$ & $\begin{array}{l}0.67 \mathrm{~d} \\
\pm 0.33 \\
\end{array}$ & $\begin{array}{c}2.0 \\
(6.67) \\
\end{array}$ & $\begin{array}{l}0.67 \mathrm{~b} \\
\pm 0.33 \\
\end{array}$ \\
\hline L.S.D & - & 1.215 & - & 0.941 & - & 1.438 & - & 1.960 & - & 1.537 & - & 0.941 & - & 0.544 \\
\hline
\end{tabular}

$A=$ (numbers \& percentages)

$B=$ Mean \pm S.E. 3 replicates; each contains 10 larvae.

Table (3) : Thee ffect of evaluated SiNPs baits on A. ipsilon larvae.

\begin{tabular}{|c|c|c|c|c|c|c|}
\hline \multirow{2}{*}{$\begin{array}{c}\text { Tested } \\
\text { compound }\end{array}$} & \multirow{2}{*}{$\begin{array}{c}\text { Bioassay } \\
\text { time (days) }\end{array}$} & \multirow{2}{*}{ Calculated $\mathrm{LC}_{\mathrm{s}}$} & \multirow{2}{*}{ Slope } & \multirow{2}{*}{$\begin{array}{c}\mathrm{LC}_{50} \\
(\mathrm{~g})\end{array}$} & \multicolumn{2}{|c|}{$95 \%$ fiducial limits } \\
\hline & & & & & Lower & Upper \\
\hline \multirow{3}{*}{ SiNPs } & \multirow{3}{*}{10} & $\mathrm{Lc}_{25}$ & \multirow{3}{*}{$\begin{array}{c}1.7893+/- \\
0.4979\end{array}$} & 0.072 & 0.017 & 0.118 \\
\hline & & $\mathrm{Lc}_{50}$ & & 0.171 & 0.096 & 0.244 \\
\hline & & $\mathrm{Lc}_{90}$ & & 0.890 & 0.503 & 5.107 \\
\hline
\end{tabular}

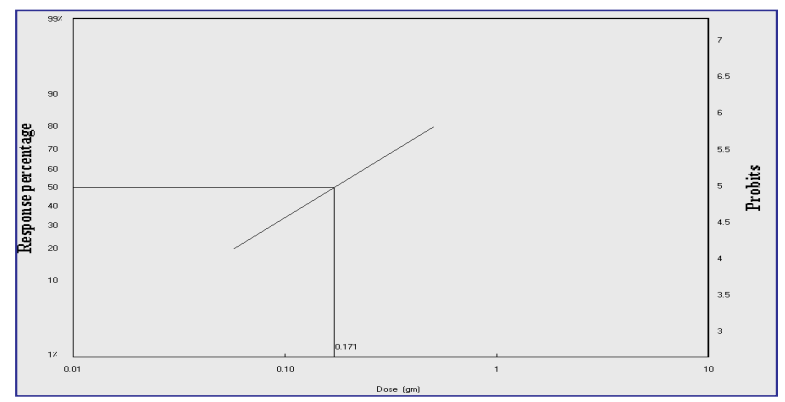

Fig. (1): The Calculated LC50 using Probit Program.

These results were in agreement with (Debnath et al., 2011) who investigated and compared the insecticidal efficacy of surface functionalized amorphous silica nanoparticle (SNP) with micron sized silica "FossilShield90.0s" on the second instar larvae of S. litura at four dose rates with proper control.
It was found that all SNPs were much more effective than "FossilShield 90.0s" especially, hydrophilic SNP that could kill all the larvae within 24 hours of treatment. Moreover, (Debnath et al., 2012) applied two types of SNPs (Spherical and monosidperse) against the second instar larvae of Spodoptera litura and found that both of these tested SNPs could effectively kill the insect larvae.

Also, (Derbalah et al., 2012) found that nanosilica was the most effective treatment against Tuta absoluta in tomato under greenhouse conditions followed by Artemisia cina, imidacloprid + A. cina, indoxacarb, filtrate of $B$. thuringiensis, imidacloprid, indoxacarb + A. cina and clove oil treatments, respectively. 
Moreover, (El-Bendary and El-Helaly, 2013) evaluated the effects of six doses $(100,150,200$, 250,300 , and $350 \mathrm{ppm}$ ) of hydrophobic nano-silica on the resistance of tomato plants to the neonates of Spodoptera littoralis under semi field conditions. Their results indicated high toxic action at all concentrations. They found also, high resistance in tomato plants against this insect-pest, especially at the tested doses of 300 and $350 \mathrm{ppm}$.

(El-Samahy et al., 2014) evaluated the efficacy of silica nanoparticles and neem oil extract at different concentrations compared with a recommended chemical insecticide (imidacloprid) against $T$. $a b$ soluta under field conditions. Using silica nanoparticles significantly reduced the numbers of $T$. absoluta larvae followed by neem oil extract compared with check (without any treatments). While there were insignificant differences between using silica nanoparticles and imidacloprid $(p<0.05)$ in controlling $T$. absoluta. Also, there were insignificant differences when analyzing the content of resulting tomato fruits from the different treatments compared to the check. However, it must be considered the residual impact of the chemical pesticide. The results also showed a significant increase in the weight and size of tomato fruits as a result of the silica nanoparticles treatment.

On the other hand (Barik et al ., 2012) tested three types of nanosilica, namely lipophilic, hydrophilic and hydrophobic, to assess their larvicidal, pupicidal and growth inhibitor properties and also their influence on oviposition behaviour (attraction/ deterrence) of mosquito species. Application of hydrophobic nanosilica at 112.5 ppm was found effective against mosquito species tested.

\section{Effect of the L $c_{50}$ concentration of silica nanoparticles on the chitin synthesis and Inorganic elements in the haemolymph:}

As previously shown, silica nanoparticales induce dehydration as a main reason behind their nanocidal property. Due to their ultra-small size,
SiNPs got impregnated in insect cuticle and damaged the cuticular water barrier. The application of nanoparticles of silica during the sensitive period of the larval metamorphic development revealed morphological abnormalities of immatures malformation that are generally irreversible and often led to death before maturation.

Silica nanoparticles are compounds of interest because they disrupt the metabolism and synthesis of chitin, a polysaccaride of particular importance to arthropods. Therefore, these compounds have their effect on cuticle components (weight, chitin and total protein). It thus appears that such compounds offer the prospect of a broad spectrum of insect control with minimal environment damage in most habitats. It seems likely that the inhibition of chitin synthesis caused by the application of these compounds is a consequence of a rapid and complete blocking of chitin synthetase enzyme rather than an activation of chitinase.

The effect of Silica nanoparticles on cuticle components of the treated A.ipsilon larvae is shown in Figure (1). After $24 \mathrm{hrs,}$, there was detectable effect observed in which the tested SiNPs decreased the cuticular dry weight, cuticular chitin and total protein, compared to untreated ons. Whereas, the mean values of the cuticular dry weight, cuticular chitin and total protein of the cuticle were 0.134 , 0.104 and $0.023 \mathrm{~g}$, for the treated larvae, compared to $0.158,0.118$ and $0.027 \mathrm{~g}$, respectively for the untreated control larvae.

\section{Haemolymph inorganic elements concentrations:}

The inorganic constituents of haemolymph such as $\mathrm{Na}+, \mathrm{K}+, \mathrm{Ca}++$ are of vital importance in view of their role in the neurophysiology of the insect and their levels inside and outside the nerve sheath membrane and they have to maintain for the propagation of impulses (Roeder, 1953).

The nervous system is very resistant to variations in the sodium potassium ratio. A large part of 
potassium in haemolymph is contained within the haemocytes and therefore does not contribute to ionic concentration in the circulating blood. $\mathrm{Na}+/ \mathrm{K}+$ ratio must be at least 1:3 and can be increased to 1:34 (Wiggelsworth, 1972).

As seen in table (5), highly clear significant differences of Potassium, sodium, calcium and phosphor concentrations in the haemolymph were observed between untreated and SNPs treated larvae. The values significantly declined and recorded 1340, 400, 600 and 443.4, respectively for the four measured inorganic elements, compared with 2431, 472, 840 and 833.7 in the control treatment.

In this concept, the revealed nanocidal property of tested SiNPs, which is attributed to the induced dehydration due to the resulted damage of cuticular water barrier; disruption of chitin synthesis; and declination of inorganic elements in the haemolymph of treated larvae needs detailed further study.

\section{The inspected types of larvae abnormalities:}

In the light of formerly elucidated observations, the obtained results of this study show that the tested baits containing nanoparticles of silica, principally, may act as insect growth inhibitors (IGIs), rather than anti-feedants, leading to the disturbance of normal biological performance within developing insect, which at least ends by death. The involved plates exhibit the revealed effects of nanoparticles of disrupted biophysiological process within the treated insects, which finally caused the prevalence of abnormal larvae of the black cutworm, $A$. ipsilon, (Photo 1).

Table (4): The calculated means of cuticular dry weight, chitin and total protein for the treated 4 th instar larvae of Agrotis ipsilon by silica nanoparticles (24 hrs post-treatment).

\begin{tabular}{|c|c|c|c|}
\hline \multirow{2}{*}{$\begin{array}{c}\text { Treatment } \\
\text { Lc }_{50}\end{array}$} & \multicolumn{3}{|c|}{ Mean / Replicate } \\
\cline { 2 - 4 } & Cuticular dry weight (g) & Cuticular chitin (g) & Total protein (g) \\
\hline $\begin{array}{c}\text { Silica nanoparticles } \\
0.171(\mathrm{~g})\end{array}$ & 0.134 & 0.104 & 0.023 \\
\hline Check untreated & 0.158 & 0.118 & 0.027 \\
\hline
\end{tabular}

Table (5): The effect of silica nanoparticles on the haemolymph inorganic elements concentration of Agrotis ipsilon larvae after 24 hours from application.

\begin{tabular}{|c|c|c|c|c|}
\hline \multirow{2}{*}{ Treatment } & \multicolumn{4}{|c|}{ Haemolymph metal ion (mg/l) } \\
\cline { 2 - 5 } & K & Na & Ca & P \\
\hline SiNPs & 1340 & 400 & 600 & 443.4 \\
\hline Check untreated & 2431 & 472 & 840 & 833.7 \\
\hline
\end{tabular}




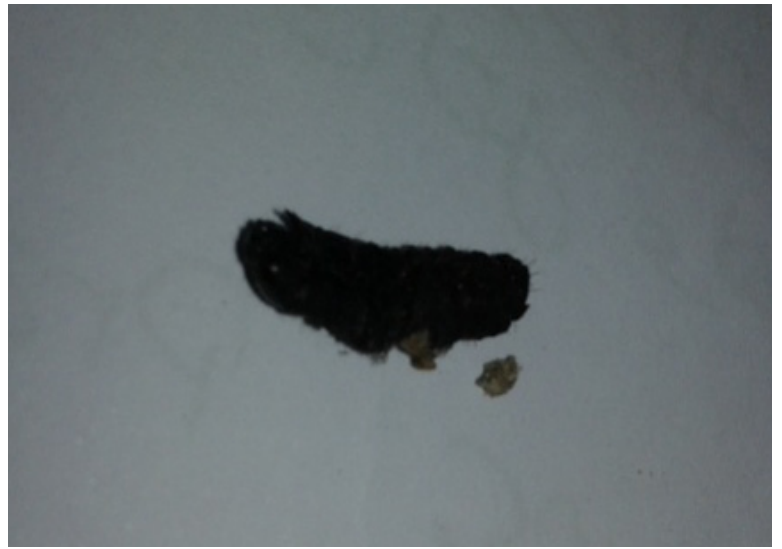

$0.1 \mathrm{~g}$ SiNPs

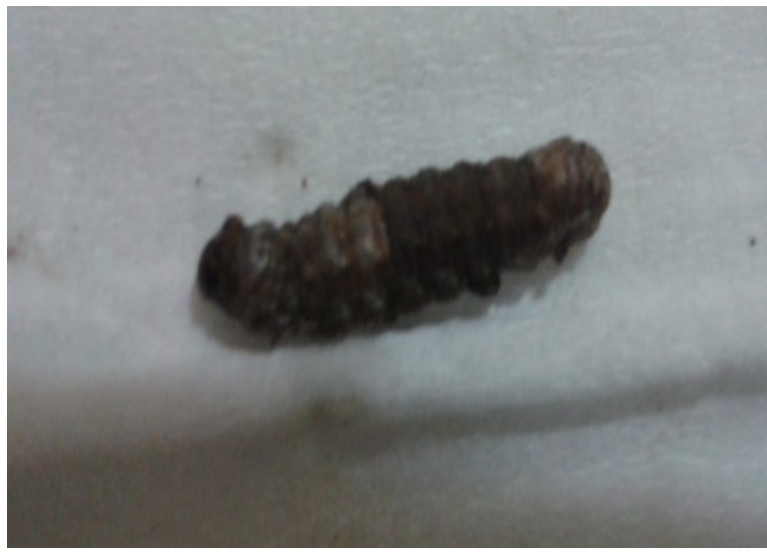

$0.5 \mathrm{~g}$ SiNPs

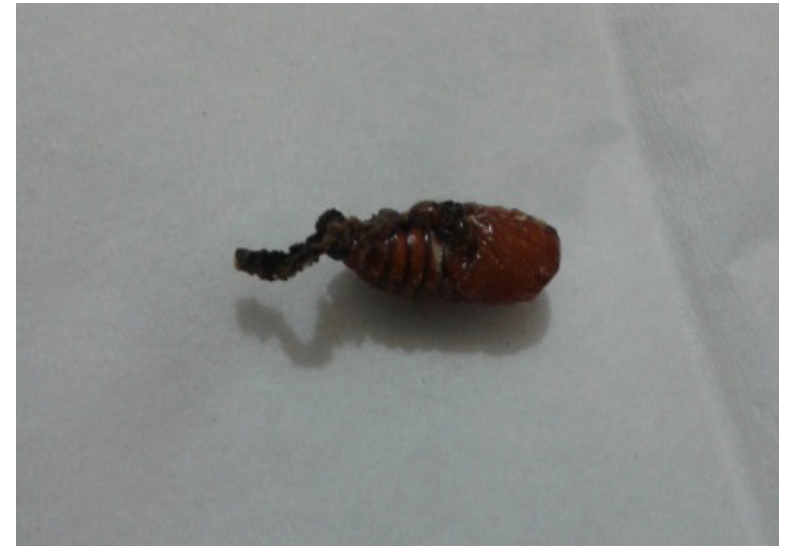

$0.25 \mathrm{~g}$ SiNPs

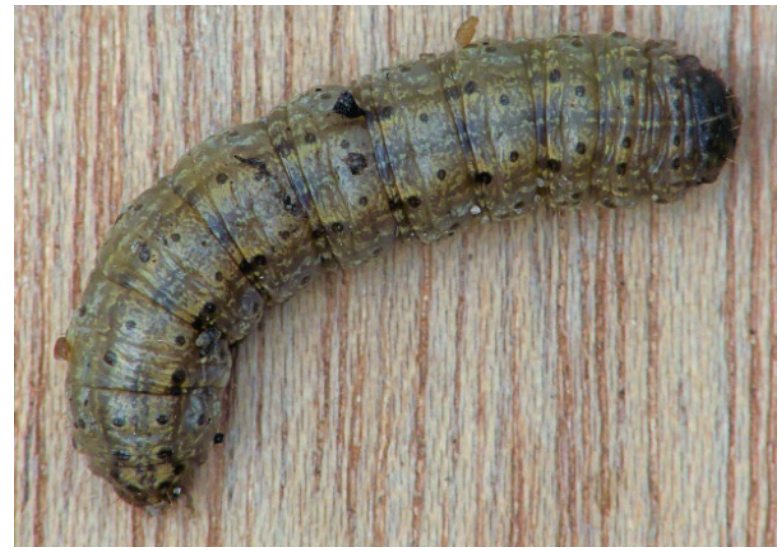

Chek untreated Agrotis ipsilon

Photo (1): Types of detected dead larvae following SiNPs treatment

\section{CONCLUSION}

The mortality percntage of larval increased up to $100 \%$ after 15 days of application against the fourth instar larvae of Agrotis ipsilon (Hufn.). The admixing of nanoparticles of silica in the bait during the sensitive period of larval development caused morphological abnormalities that are generally irreversible and often lead to death, beside certain biochemical changes of some inorganic elements in the haemolymph of the treated insects.

\section{REFERENCES}

- Abdel-Hadi, M.A. (1968): Biological and ecological studies on Agrotis ipsilon. Ph. D. Thesis, Fac. Agric., Cairo Univ.
- Abdel-Mageed, A.A.F. (1997): Insecticidial activity of Bacillus thuringensis and its mixtures with pesticides against Agrotis ipsilon. M.Sc. Alex. Univ., Egypt, 118.

- Abbott, V.S. (1925): A method of computing the effectiveness of an insecticide. J. Econ. Entomol., 18: 265.

- Barik, T.K.; Kamaraju, R. and Gowswami, A. (2012): Silica nanoparticle: a potential new insecticide for mosquito vector control. Parasitol. Res., 111(3): 1075 .

- Beheedy, A.A. (1990): Toxicological and histopathological studies on Agrotis ipsilon (Hufn). Ph.D.,Faculty Agric., Alex.Univ., Egypt.

- Debnath, N.; Das, S. and Goswami, A. (2011): Novel entomotoxic nanocides for agro-chemical industry. 
International Conference on Nanotechnology Portland Marriott August 15-18, Portland, Oregon, USA.

- Debnath, N.; Mitra, S.; Das, S. and Goswami, A. (2012): Synthesis of surface functionalized silica nanopanicles and their use as entomotoxic nanocides. Powder Technol., 221: 252.

- Derbalah, A.S; Morsey, S.Z. and El-Samahy, M. (2012): Some recent approaches to control Tuta absoluta in tomato under greenhouse conditions. African Entomol., 20(1): 27.

- Duncan, D.B. (1955): Mutiple range and multiple F. Tests. Biometrices., 11: 1-4.

- Ebeling, W. (1971): Sorptive dusts for pest control. Ann. Rev. Entomol.,16: 123.

- El-bendary, H.M. and El-Helaly, A.A. (2013): First record nanotechnology in agricultural: Silica nanoparticles a potential new insecticide for pest control. App. Sci. Report, 4(3): 241

- El-Kifl, A.H.; Nasr, E.A.; Ibrahim M.N. and Moawad, G.M. (1972): Effect of host plants on various stages of Agrotis ipsilon. Bull. Soc. Ent. Egypt, LVI: 103.

- El-Samahy, M.F.M; El-Ghobary, A.M. and Khafagy, I.F. (2014): Using silica nanoparticles and neem oil extract as new approaches to control Tuta absoluta (Meyrick) in tomato under field conditions. Int. J. Plant \& Soil Sic., 3(10): 1355.

- Finney, D.J. (1971): Probit Analysis $3^{\text {rd }}$ edition, Cambridge University Press, Cambridge, U.K., PP. 333.

- Golob, P. (1997): Current status and future perspectives for inert dusts for control of stored-product insects. J. Stored Prod. Res., 33: 69.

- Gopal, M.; Kuraar, R. and Goswami, A. (2012): Nano-pesticides - A recent approach for pest control. Plant Prot. Sci., 4(2): 1.

- Hackman, R.H. and Goldberg, M. (1971): Studies on the hardening and darkening of insect cuticles. $J$. Insect Physiol., 17: 335.
- Hazaa, M.A.M. and Aim El-Din, M.M.S. (2011): Synergistic effect of the insect growth regulator, Neporex to gamma radiation on the black cutworm, Agrotis ipsilon, Isotope \& Rad. Res., 43(3): 855.

- Han, Z.J. (1986): The virulence reaction and fastness variation of the black cutworm to several pesticides. J. Acta Phytophylacica Sini., 13(2):125.

- Kandil, M.A; Abdel-Aziz, N.F. and Sammour, E.A. (2003): Comparative toxicity of chlorfluazuron and leufenuron against cotton leaf worm Spodoptera littoralis (Boisd.). Egypt. J. Agric. Res., 2: 645.

- Korunic, Z. (1998): Diatomaceous earths, a group of natural insecticides. J. Stored Prod. Res., 34: 87.

- Li, F.; Chen, J.C. and Chen, J.H. (2002): Effects of $\mathrm{Bt}$ on respiration of the larvae of Agrotis ipsilon (Rottemberg). J. Nat. Enemies Insects, 24: 15.

- Li, Q.Y.F. and Zhang, G.A. (2008): Investigation of harming conditions of black cutworm, Agrotis ipsilon (Rottemberg) and the control of its insecticide in corn fields of North-West of Qian. J. Bull. Anhui. Agric. Sci., 14: 172 .

- Roeder, K.D. (1953): Insect Physiology. John Wiley and Sons Inc, NY. 178: 1236-1237.

- Salama, H.S.; Dimetry N.Z. and Salem S.A. (1970): On the host preference and biology of the cotton leaf worm Spodoptera littoralis. Z. Ang. Entomol., 67: 261.

- Schmidt, G.H. (1986): Pestiside undumweltschutz. Vieweg \& Sohu, Braunschweig, 466 pp.

- Shakur, M.; Ullah, F.; Naem, M.; Amin, M.; Saljoqi, A.U.R. and Zamin, M. (2007): Effect of various insecticides for the control of potato cutworm (Agrotis ipsilon Huf., Noctuidae: Lepidoptera) at Kalam Swat. Sarhad J. Agric., 23(2): 423.

- Slathers, T.E.; Denniff, M. and Golob, P. (2004): The efficacy and persistence of diatomaceous earths admixed with commodity against four tropical stored product beetle pests. J. Stored Prod. Res., 40(1): 113. 
- Subramanyan, B. and Roesli, R. (2000): Inert dusts, pp. 321-380. Alternatives to pesticides in stored product IPM (Subramanyan B. and Hagstrum D. W., Eds). Kluwer Academic Publishers, Boston, USA.

- Warheit, D.B.; Sayes, C.M.; Reed, K.L. and Swain, K.A. (2008): Health effects related to nanoparticle exposures: environmental, health and safety considerations for assessing hazards and risks. Pharm. Therap., 120(1): 35 .

- Wigglesworth, V.B. (1972): Principles of Insect Physiology (Chapma $\mathrm{n}$ and Hall, London. 